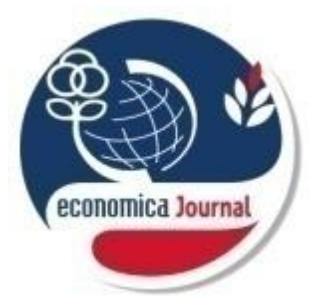

\title{
POLICY ANALYSIS OF THE DEVELOPMENT OF SMALL AND MEDIUM COFFEE INDUSTRIES IN SOLOK DISTRICT
}

\author{
By \\ Mahdi $^{1)}$, Rian Hidayat ${ }^{2)}$, Lora Triana ${ }^{3)}$ \\ ${ }^{1)}$ Program Study of Agribusiness, Faculty of Agriculture, Andalas University \\ Email: mahdi@agr.unand.ac.id \\ 2) Program Study of Agribusiness, Faculty of Agriculture, Andalas University \\ Email: rianhidayat@agr.unand.ac.id \\ 3) Program Study of Agribusiness, Faculty of Agriculture, Andalas University \\ Email: loratriana@agr.unand.ac.id \\ Submitted: 2020.11.01 Reviewed: 2020.11.13 Accepted: 2021.04.30 \\ https://doi.org/10.22202/economica.2021.v9.i2.4442
}

\begin{abstract}
Regional autonomy policy, giving authority to the government of Solok District to formulate and establish policies for the development of small and medium coffee industries (SMIs Coffee). The objective of this research is to describe the policy for the development of the SMIs coffee in Solok District and provide ideas for the development of the SMIs in Solok District. The research used a qualitative descriptive method. Data were collected by conducting in-depth interviews and Desk Study. Qualitative data analysis is (1) data reduction, (2) display data, and (3) concluding. The variables observed in the research are central government policies in the form of Laws and Government Regulations concerning industrial development, particularly on SMIs. The local government policies studied are Regional Regulations and Regent Regulations concerning the development of SMIs coffee in Solok District. for the development of SMIs, the central government has issued Law No. 3/2014 concerning industry and Government Regulation No. 29/2018 concerning industrial empowerment, wherein this policy, the central government asks local governments to develop small and medium industries (SMIs) so that they have competitiveness. The results of this study are (1) the District Government of Solok does not yet have a Regional Regulation on the development of SMI) Coffee and other SMIs. The policy that Solok District already has is the Decree of the Regent of Solok No. 510-265-2018 concerning the Development of SMIs Clusters. The SMIs cluster which is prioritized in the Solok Regent Decree is the category of Food SMIs and Craft SMIs, while Coffee SMIs do not yet exist, (2) to develop the downstream coffee that has been carried out by SMIs in Solok District, the local government of Solok District needs to do 4 important things, namely formulating and establishing policies in the form of regional regulations, strengthening institutional capacity, providing facilities and establishing digital marketing clinics for Coffee SMIs.
\end{abstract}

Jel Classification:

Q58; $L 7$

Keywords: Policy, Industry, Coffee, Solok, SMIs

(C2021 Prodi Pendidikan Ekonomi STKIP PGRI, Padang

INTRODUCTION 
Indonesia is an important producer and consumer of coffee in the world. As a producer, Indonesia ranks fourth in the world, after Brazil, Vietnam, and Colombia, as a consumer at seventh. Meanwhile, as a plantation product in Indonesia, coffee ranks sixth after palm oil, rubber, sugar, tea, and cocoa (Dirjen IKM, 2017).

Based on data from the Central Statistics Agency of West Sumatra Province, Solok District has the highest plant area and coffee producer from smallholder coffee in West Sumatra Province, however, the trend of coffee production in Solok District for the period 2011 to 2017 has decreased. To trigger an increase in coffee production in Solok District, a downstream agribusiness policy is needed, one of which is the development of Small and Medium Coffee Industries. The development of Small and Medium Coffee Industries will be an attraction for activities to increase coffee production because the processing industry will need coffee raw materials for its production. In the national policy, the coffee processing industry is one of the mainstay industries as described in the 2015-2035 National Industrial Development Master Plan, which is included in the food industry group in the category of the freshener industry.

To mobilize the regional economy, Small and Medium Industries (SMIs) are dealing with several problems. Internal problems include capital problems, financial administration problems, regeneration problems, or single management problems, and other human resource problems. External problems include limited infrastructure owned by SMIs and the business climate such as competition, marketing, technology, and government policies (Lestari, 2005).

Based on these problems, the researchers are interested in observing and studying external problems, especially regarding government policies for the development of small and medium coffee industries in Solok District. Whether the policies formulated and stipulated by the local government of Solok District have focused on the downstream coffee carried out by small and medium-scale processing industries.

For the development of SMIs, the central government has issued Law No. 3/2014 concerning industry and Government Regulation No. 29/2018 concerning industrial empowerment. wherein this policy, the central government asks local governments to formulate policies for the development and empowerment of small and medium industries (SMIs) so that they have competitiveness. Has the local government started to formulate this SMIs policy? because previously the Solok district government focused on Small and Medium Enterprises (SMEs). The objective of this research is to describe policies for the development of small and medium industries (SMIs) coffee in Solok District and provide ideas for the development of SMIs coffee in Solok District.

\section{METHODS}

The research was conducted in Solok District, which has the largest plant area and coffee producer in West Sumatra Province. The method used in this study used a qualitative descriptive method approach. Data collection was done by the In-Depth interview and Desk Study. In-depth interviews were used to obtain information from key informants on policies for the development of the small and medium coffee industry in Solok District, and Desk Studies were used to study official government documents, policies, and regulations on coffee development in Solok District.

Collection of primary data and secondary data related to policies in the development of small and medium coffee industries in Solok District from the Office of Cooperatives, Small and Medium Enterprises, Industry and Trade of Solok District, Agriculture Office of Solok District, Office of Communication and Informatics of Solok District, and Office of 
Planning, Research and Development of Solok District.

The variables observed in this study were, a). Central government policy variables in the form of laws and government regulations relating to industrial empowerment, particularly small and medium industries, b). Local government policy variables in the form of regional regulations and Regent Regulations relating to the development of small and mediumscale coffee processing industries.

The variables observed in this study were, a). Central government policy variables in the form of laws and government regulations relating to industrial empowerment, particularly Small and Medium Industries, b). Local government policy variables in the form of regional regulations and the Solok Regent Regulation relating to the development of small and medium-scale coffee processing industries.

To answer the research objectives, using a qualitative descriptive method. According to Indriantoro (2002) Qualitative descriptive analysis is to describe and describe existing phenomena, both natural and human engineering, which pay more attention to the characteristics, quality, linkages between activities, and stages in data processing carried out are, a). Data reduction, namely the researcher selects and sorts the collected data, b). Data display, namely the author displays the data that has been selected, c). In conclusion, the researcher concludes and provides analysis from the data that has been presented.

\section{RESULTS AND DISCUSSION \\ Policy for the Development of Small and Medium Coffee Industries in Solok District}

Law No. 3/2014 concerning Industry has placed the industrial sector as one of the pillars of the national economy and is expected to play a role in encouraging the progress of the national industry. This role is needed in directing the national economy to grow faster and catch up with other countries. Law No. 3/2014 is a policy that regulates the development of the national industry of the Republic of Indonesia to replace Law No. 5/1984 concerning the industry.

According to Law No. 3/2014, the objective of implementing industry is to create a competitive industry, open business opportunities, expand job opportunities, and improve people's welfare. The main points of regulation in Law No. 3/2014 are 14 fields, and one of the fields is the empowerment of small and medium industries. In Chapter VIII, the first part specifically describes the small and medium industries. Article 72 explains that local governments are asked to empower small and medium-sized industries so that they can compete and play a role in poverty alleviation through expanding job opportunities.

The provisions concerning the empowerment of small and medium industries have also been further explained in Government Regulation No.29/2018 concerning industrial empowerment. Article 3 explains that the central government and/or local governments undertake development and empowerment of SMIs to create competitive SMIs, play a role in strengthening the national industrial structure, play a role in poverty alleviation through expanding employment opportunities, and produce industrial goods and/or services for export.

To realize SMIs according to the ideals of Government Regulation No.29/2018, the local government oversees the formulation and determination of policies, strengthening institutions, and providing facilities to small and medium industries (SMIs). Strengthening of institutions and providing facilities to SMIs refers to the formulation of local government policies, while the formulation of local government policies on small industries and refers to regional industrial resources, national industrial structures, national and global economic development.

The mandate is to formulate and determine policies for the empowerment of 
small and medium industries in line with the regional autonomy policy which gives authority to the local government of Solok District. The implementation of regional autonomy as stipulated in Law No. 23/2014 concerning Regional Government is directed at accelerating the realization of community welfare through improved services and community empowerment as well as increasing regional competitiveness. The role of the Regional Government as the executing authority of the autonomous regional government will greatly determine the development of small and medium industries.

Efforts to develop small and medium industries must be more professional, better, and more equitable throughout Indonesia, therefore the development of small and medium industries must be carried out in a focused manner on each region because the development of small and medium industries nationally is ineffective and has experienced many failures, as well as small and medium industrial development, must focus according to the needs of each region. (Hitokdana, 2018).

The formulation of policies by local governments regarding small and medium industries refers to local resources. One of the regional potentials in Solok District is having the largest area of coffee plantations in West Sumatra Province, so this potential can be turned into raw material for the small and medium scale industrial sector to realize regional progress. The area of coffee plants in Solok District is based on data from the Central Statistics Agency (BPS) of West Sumatra (2019) that in 2018 the area of coffee plants in Solok District was 8,258 hectares consisting of 6,549 hectares of robusta coffee plants and 6,549 hectares of arabica coffee. 1,709 hectares, while coffee production in Solok District in 2018 was $2,455.2$ tons, which came from the robusta coffee plant of 1,583 tons and arabica coffee plants of 872.2 tons.

Processed products made from coffee raw that have been carried out by the community in Solok District are into coffee powder. This coffee powder processing business has increased the added value of coffee beans, absorbed labor, and increased community welfare, while processing coffee beans into other products has not been carried out in Solok District. The coffee powder processing business is not well developed in Solok District compared to other districts. The number of coffee powder processing industries in Solok District is 34 business units, while Tanah Datar District with an area of only 1,880 hectares of coffee powder has 206 business units. (Hidayat, 2019)

Based on the Regional Regulation of Solok District No. 4/2016 concerning the 2016-2021 Regional Medium-Term Development Plan, the Agency which carries out matters related to Small and Medium Industries (SMIs) is at the Office of Cooperatives, Small and Medium Enterprises, Industry, and Trade of Solok District. This agency plays a role in increasing the competitiveness of Small and Medium Industries so that they have an impact on creating jobs, equal distribution of income, economic growth, and poverty alleviation. However, until now, the Solok District Government has not had a Regional Regulation on the development of small and medium-sized industries (SMIs) as mandated by Government Regulation No. 29/2018 concerning industrial empowerment.

For the development of small and medium industries (SMIs) in Solok District, the policy that Solok District already has is the Decree of the Solok Regent No. 510265-2018 concerning the Establishment of Small and Medium Industry Clusters in Solok District. This decree was issued to provide a legality aspect in providing guidance and guidance for the development of small and medium industries in Solok District. In the Decree of the Regent of Solok No. 510-265-2018, it is explained about the guidance and development of small and medium industries, as well as establishing small and medium industrial centers (SMIs) in Solok District. According 
to Government Regulation No. 29/2018, what is meant by Sentra SMIs is a group of SMIs in one location/place consisting of at least 5 (five) business units that produce similar products, use similar raw materials, and/or carry out the same production process.

Based on the Decree of the Regent of Solok No. 510-265-2018, the number of SMIs centers formed is 15 SMIs cluster, 1). SMIs cluster for Tenun Usaha Mulya, 2). SMIs cluster for Batik Tulis Ayam Kukuak Balengek, 3). SMIs cluster for Bordir Putri Sulita, 4). SMIs cluster for Gula Tebu, 5). SMIs cluster for Kareh-Kareh, 6). SMIs cluster for Minyak Atsiri, 7). SMIs cluster for Aneka Kerupuk, 8). SMIs cluster for Aneka Keripik, 9). SMIs cluster for Aneka Stick, 10). SMIs cluster for Aneka Kerupuk Ubi, 11). SMIs cluster for Aneka Rakik, 12). SMIs cluster for Tapai, 13). SMIs cluster for Tahu and Tempe, 14). SMIs cluster for Apar Besi, and 15). SMI cluster for Daruakdaruak. The types of SMIs included in the decision of the Regent of Solok are categorized as Food SMIs and Craft SMIs. However, Coffe SMIs is not included in the SMIs cluster which will be guided and fostered based on the Decree of the Regent of Solok No. 510-265-2018.

Activities that have been carried out by the Office of Cooperatives, Small and Medium Enterprises, Industry and Trade of Solok District in the 2019 budget are related to the development of Small and Medium Industries (SMIs) are the development of standardization of testing and packaging quality, guidance in strengthening industrial cluster networks, formulating industrial policies related and supporting industries, expanding the application of SNI to encourage the competitiveness of the manufacturing industry, and fostering the linkages of upstream to downstream industrial production. The target groups of these activities are dominated by Metal SMIs, Furniture SMIs, Food SMIs, Weaving SMIs, and drafting RPIK regional regulations (Dinas KUKMPP, 2019).
Activities that have been carried out by the Office of Cooperatives, Small and Medium Enterprises, Industry and Trade in Solok district in the 2020 budget are related to the development of Small and Medium Industries (SMIs) are increasing competitiveness and marketing of SMIs products through PIRT Training, increasing competitiveness and marketing of SMIs products through development. cashless payment systems and e-commerce marketing for SMIs, entrepreneurial knowledge for SMIs. The target groups for this activity are dominated by food SMIs and Metal SMIs. (Dinas KUKMPP, 2020).

According to the Dirjen IKM (2018), the problems that must be considered and resolved by SMIs business actors are a). There are still quality standards (quality) of products that are not consistent, do not meet standards, both national and international standards, especially in terms of raw materials, product size, delivery time, b). Inability to keep up with dynamic technological changes followed by a costly increase, c). The increasingly high market competition requires adequate information and transportation facilities to achieve wider market access, d). Limited access to business capital from financial institutions, both private and government, with light and affordable requirements, e). Changes in very dynamic consumer tastes require continuous creativity and innovation, while according to Dinas KUKMPP of Solok District (2020), the problems faced in developing SMIs in Solok District are generally weak access to capital, weak packaging design capabilities, limited capacity. product marketing, lack of facilities, and infrastructure for industrial centers, lack of understanding of the importance of quality standards such as processing PIRT permits and halal certification.

Policy Ideas for the Development of Small and Medium Coffee Industries (SMIs Coffee) in Solok District.

Solok District has natural resources as the largest coffee producer in West Sumatra 
Province, so it can be an opportunity to drive regional economic development. The downstream of coffee products that have been carried out by small and medium industries (SMIs) in Solok District is to become coffee powder so that the coffee powder SMIs have become one of the economic actors in the regions that can empower the regional economy. To empower the local economy with small and medium-scale processing industries, especially the downstream coffee products, the local government of Solok District must formulate a policy for the development of Coffee SMIs and other SMIs with the model in Figure 1. For the development of Coffee SMIs in Solok District, 4 important things are needed, namely the formulation and stipulating policies in the form of regional regulations, strengthening institutional capacity, providing facilities, and establishing digital marketing clinics.

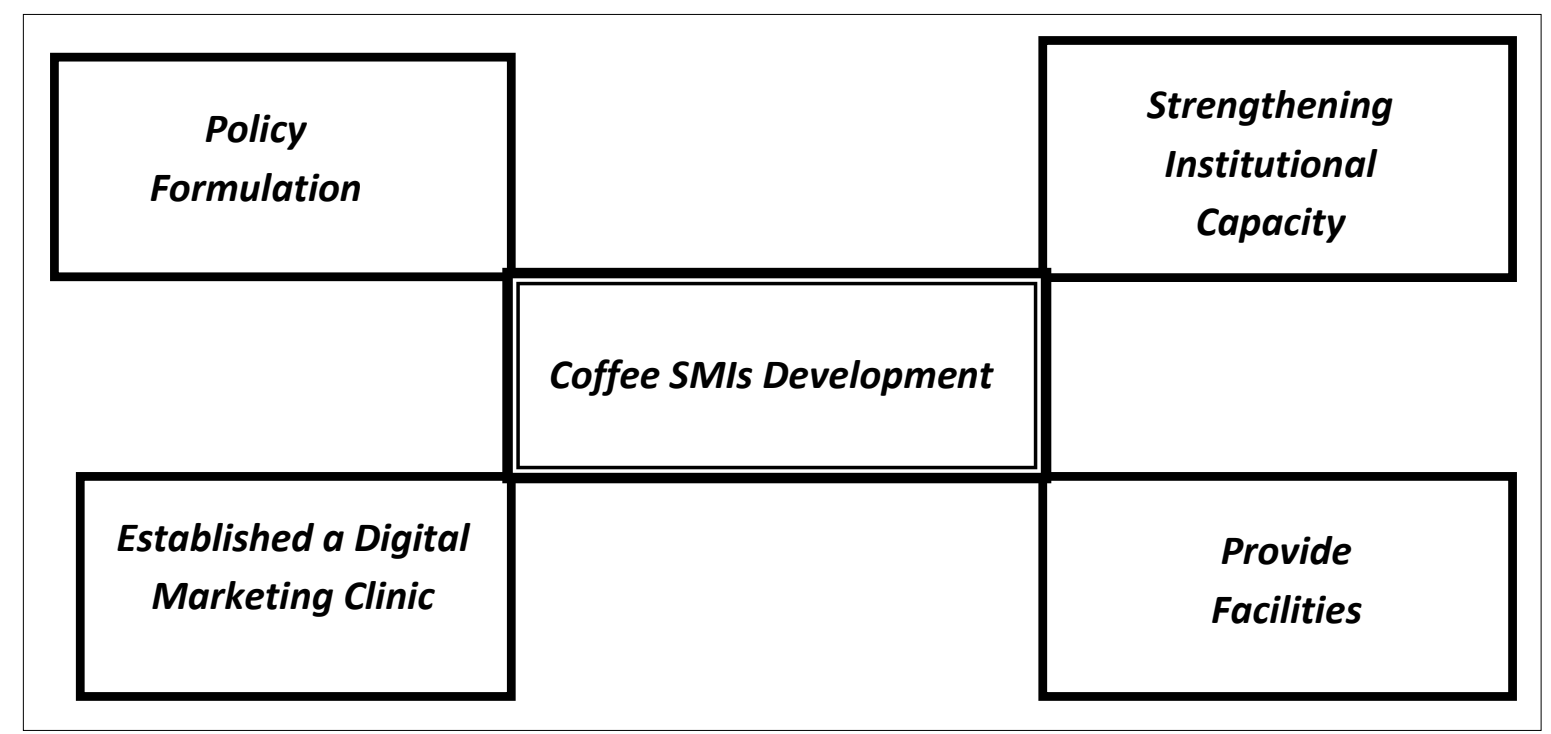

Figure 1. Policy Ideas for the Development of Small and Medium Coffee Industries (SMIs Coffee) in Solok District.

\section{Policy Formulation}

Solok District does not have a policy in the form of a regional regulation on the development of Small and Medium-sized Industries (SMIs) for Coffee and other SMIs. This is a problem that needs to be resolved immediately, namely by providing legality in the development of the Coffee and other SMIs in Solok District. The Regional Government of Solok District must immediately formulate and enact Regional Regulations concerning the development of Small and Medium Industries (SMIs) as mandated by Law No. 3/2014 concerning Industry. By formulating and enacting local government policies in the form of regional regulations, it shows that local governments pay serious attention to the development of Small and Medium
Industries (SMIs). In the formulation of local regulations regarding the development of Coffee and other SMIs, it must cover the scope of strengthening institutional capacity, providing facilities, and establishing digital marketing clinics. The formulation of local regulations on the development of small and medium-sized coffee industries (SMIs) is very important, namely in the context of developing downstream coffee beans.

According to the Dirjen PerundangUndangan (2011) that the function of regional regulations is, a) as a policy instrument for implementing regional autonomy, b) is an implementing regulation of higher laws and regulations. c) as a means of accommodating the specificity and diversity of the region and channeling the aspirations of the 
community in the region, d) as a development tool in improving regional welfare. However, according to Rustandi (2017), regional regulations stipulated by regions must not conflict with the provisions of higher-level statutory regulations following the hierarchy of statutory regulations, as well as the content of Regional Regulations which includes regulating the elaboration of higher regulations, and arrangements regarding the special conditions or characteristics of each region.

\section{Strengthening Institutional Capacity}

For the development of SMIs Coffee in Solok District, the local government must also strengthen its institutional capacity. One of the efforts is to build clusters or centers for Small and Medium Industries (SMIs), including the SMIs Coffee. Currently, Solok District already has a SMIs cluster based on Solok Regent Regulation No. 510-265-2018, but in the Decision of the Solok Regent, the SMIs coffee cluster does not yet been established.

According to Marijan (2005), the development of SMIs through the cluster approach can increase the competitiveness of SMIs, and according to Dayasindhu (2002) Through clusters, new knowledge transfer will develop among small and medium industry players, and according to Alberti and Giusti (2012) that clusters will also foster collective innovation and regional competitiveness, meanwhile according to Morosini (2004), that a new knowledge obtained by small and medium industries will lead to new ideas. New knowledge will easily be formed if the industries and other supporting institutions are located in certain geographical proximity or known as clusters. The accumulation of new knowledge will give rise to innovation in industry and apply it as part of the production and final products, so that if this theory is understood, then the small and medium industrial centers have the goal of creating a transfer of new knowledge and will trigger collective innovation in various aspects of management.

Other activities to strengthen the SMIs Coffee institution in Solok District are building partnerships with large regional or national scale industries, educational and research institutions as well as industry associations engaged in the downstream coffee industry. partnerships with large-scale regional and national scale industries in the form of involvement and linkages of Small and Medium Coffee Industries (SMIs) in the supply chains of large regional and national industries. Large regional and national scale industries that involve small and medium scale industries in the industrial value chain can be given incentives by the Regional Government of Solok District, while cooperation with educational institutions and professional associations is for apprenticeship activities, business incubators, market research, utilization of research results, development. product and packaging design, and other technical and managerial guidance.

To strengthen the SMIs institution in the area of each SMIs center or clusters, assistance and guidance are needed for the development of Small and Medium Industries (SMIs) in Solok District to become competitive. The Office of Cooperatives, Small and Medium Enterprises, Industry, and Trade of Solok District can procure and train special assistants for SMIs Coffee and other SMIs, as has been done in the field of Cooperatives. To strengthen the field of cooperatives, the local government has 16 assistants.

\section{Provide Facilities}

For the development of coffee SMIs that are competitive and able to expand business and job opportunities, it is necessary to provide facilities ranging from raw materials, production processes, and marketing. The form of providing 
facilities according to SMIs Coffee needs such as technical assistance, raw material assistance, machine and equipment assistance, product development assistance, access to finance, market information assistance, promotion, and marketing. Nurcomariah (2020) one of the priority strategies in agribusiness development is government policy to increase incentives for production subsidies.

Facilitating raw material assistance is in the form of guidance on quality standards of raw materials and guidance on the provision and storage of raw materials. Facilitating production process assistance is in the form of production layout guidance, machine and equipment assistance, production quality standard guidance, as well as facilitating marketing assistance in the form of participating in exhibitions and competitions, promotion in digital form, packaging design, assistance with market information and financing, market test assistance, internet technology assistance, and other product development assistance.

\section{Established a Digital Marketing Clinic}

Providing facilities to SMIs Coffee starting from raw materials, production processes to downstream products is expected to increase product quality. The entire facilitation given is to achieve Good Manufacturing Practices (GMP). Good Manufacturing Practices is a system that ensures an industry can produce good products, so the minimum standards must be met throughout the entire production chain, from raw materials to final products to produce good and consumable products. (Dirjen IKM, 2019)

Based on national data, the growth of Small and Medium Industries (SMIs) continues to increase, the number of SMIs business units in 2015 was 3.68 million and increased to 4.41 million in 2016 and in 2017 the second quarter reached 4.59 million units effort. The added value of SMIs from year to year also continues to increase, in 2015 the added value of SMIs reached IDR 439.86 trillion, and in 2016 increased to IDR 510.88 trillion, and in 2017 the second quarter reached IDR 540.88 trillion. (Dirjen IKM, 2018), and the number of SMIs in Solok District in 2016 is 3,502 Business Units (Dinas KUKMPP, 2020)

Digital marketing at the centers of Small and Medium Industries (SMIs) coffee powder in West Sumatra Province is Tanah Datar District, which has been producing for a long time, with an average of 18.1 years. The small and medium-sized coffee industry of coffee powder has been operating for 35 years and the newest is 8 years. The application of internet marketing at SMIs Coffee powder in Tanah Datar District is still low is 30\%, and the application of standardization of products that already have a P-IRT Certificate is $73,3 \%$ and those that already have a Halal Certificate are $14 \%$, while the most widely used for packaging ground coffee in Tanah Datar district is pillow pouch using plastic as much as $94 \%$, this shows the difficulties of Small and Medium Industries (SMIs) in facing global competition (Hidayat, 2019). According to Purnomo (2017), several problems that must be resolved in small and medium industries (SMIs) are related to simple technological capabilities, uncompetitive human resource capabilities, low information mastery abilities, lack of networks, and distribution.

Dewi (2020) one of the problems in micro, small and medium enterprises to develop a business is to expand market access, so to increase competitiveness it is necessary to use information technology as a promotion and expand market networks.

To keep pace with the growth of SMIs by solving SMIs problems in the downstream part of the product, it is important to establish a digital marketing clinic. Digital marketing clinics are a medium of interaction between small and medium industry players and local governments in Solok District. Interaction 
can be done with face-to-face consultation, call center media, or other interactive media. The digital marketing clinic is to strengthen the downstream of SMIs Coffee and other SMIs products in Solok District. Digital marketing clinic activities to strengthen the downstream of SMIs Coffee products are focused on helping product design, packaging and brand design, packaging printing, product promotion via the internet, guidance on product standardization, pricing, marketing in the marketplace, partnerships, market information, and consultation on knowledge. regarding other digital marketplaces.

The development of digital marketing requires SMIs Coffee to make adjustments to their knowledge and skills, but SMIs Coffee business actors experience difficulties and limitations in following the development of digital marketing technology. The difficulties and limitations of these SMIs actors must be taken over by the local government of Solok District through a digital marketing clinic. The existence of a digital marketing clinic in Solok District will help the products of SMIs Coffee and other SMIs compete in the global world because they can be seen and transact wherever and whenever. According to Setiawan (2018) that online marketing by Micro, Small and Medium Enterprises (MSMEs) of food in the Cibinong District has succeeded in increasing the income of MSMEs between $10 \%-32 \%$.

\section{CONCLUSION}

Law No. 3/2014 on the industry in Chapter VIII specifically describes Small and Medium Industries (SMIs), where local governments are asked to develop small and medium-sized industries (SMIs). To realize the ideals of the central government to have SMIs that are competitive, it is explained in the next policy, namely in Government Regulation No. 29/2018 concerning industrial empowerment, that local governments must formulate and determine policies, strengthen institutional capacity and provide facilities to small industries and medium (SMIs). The formulation and stipulation of policies by local governments in the form of regional regulations must refer to regional industrial resources, and strengthening institutional capacity and providing facilities to SMIs must be contained in the formulation of regional government policies. One of the regional resources owned by Solok District is that it has the largest area of coffee plants and production in West Sumatra Province, but the coffee processing industry has not developed properly. The Regional Government of Solok District does not yet have Regional Regulations concerning the development of small and medium-sized industries (SMIs) for Coffee and other SMIs as mandated by Law No. 3/2014 and Government Regulation No. 29/2018. For the development or empowerment of small and medium industries (SMIs) In Solok District, the policy that Solok District already has is the Solok Regent Decree No. 510-265-2018 concerning Small and Medium Industry Centers in Solok District. The SMIs centers that were the priority in the decision of the Regent of Solok were the categories of Food and Craft SMIs, while Small and Mediumsized Industries (SMIs) for Coffee were not included in the SMIs cluster that would be assisted and fostered. For the development of SMIs Coffee in Solok District, 4 important things need to be done, namely the formulation and stipulation of policies in the form of regional regulations, strengthening institutional capacity, providing facilities, and establishing digital marketing clinics.

\section{Acknowledgment}

The author would like to thank the funding support for this research from the 2020 PNBP budget, Faculty of Agriculture, Andalas University. 


\section{REFERENCES}

Alberti, Fernando G.and Jessica, D. Giusti. 2012. Cultural heritage, tourism, and regional competitiveness: The Motor Valley cluster. City, Culture, and Society 3 (4): Pages 261-273.

Badan Pusat Statistik Propinsi Sumatera Barat. 2019. Propinsi Sumatera Barat Dalam Angka 2019. Padang.

Dayasindhu, N. 2002. Embeddedness, knowledge transfer, industry clusters, and global competitiveness: a case study of the Indian software industry. Technovation 22 (9):551560.

Dewi, Mariena, dan Musa Hubeis, Etty Riani. 2020. Marketing Strategy UMKM in Improving the Competitiveness of The Modern Retail Market in the Careffour (Cases on PT MadaniFood, Jakarta). Jurnal Manajemen Pengembangan IKM. Vol. 15 No. 1 Februari (2020) : $77-83$.

Dinas KUKMPP (Koperasi, Usaha Kecil Menengah, Perindustrian dan Perdagangan). 2019. Recana Kerja dan Anggaran (RKA) Bidang Industri. Solok.

Dinas KUKMPP (Koperasi, Usaha Kecil Menengah, Perindustrian dan Perdagangan). 2020. Recana Kerja dan Anggaran (RKA) Bidang Industri. Kabupaten Solok.

Dinas KUKMPP (Koperasi, Usaha Kecil Menengah, Perindustrian dan Perdagangan). 2020. Rencana Kerja Dinas KUKMPP Kabupaten Solok Tahun 2020. Kabupaten Solok.

Dirjen IKM. 2017. Peluang Usaha IKM Kopi. Kementerian Perindustrian Republik Indonesia. Jakarta.

Dirjen IKM. 2018. Gema; Produk Industri Kecil dan Menengah (IKM) Go Global. Edisi 60. Kementerian Perindustrian Republik Indonesia . Jakarta

Dirjen IKM. 2019. Gema; Standarisasi Produk, Tingkatkan Daya Saing IKM. Edisi 64. Kementerian
Perindustrian Republik Indonesia. Jakarta.

Dirjen Perundang-Undangan. 2011 Panduan Praktik Memahami Perancangan Peraturan Daerah. Kementerian Hukum dan HAM. Jakarta.

Hidayat, Rian dan Lora Triana. 2019. Kajian Penerapan Internet Marketing, Standarisasi Produk dan Desain Kemasan Oleh Industri Kecil dan Menengah (IKM) Kopi Bubuk Di Kabupaten Tanah Datar. Universitas Andalas.

Hitokdana, Sebedeus. 2018. Efektivitas Kebijakan Pemerintah Daerah Terhadap Pengembangan Industri Kecil dan Menengah di Kota Jaya Pura. Jurnal Law and Justice Vol. 3 No. 1 April (2018).

Indriantoro, Nur dan Supomo, Bambang. (2002). Metodologi Penelitian. Edisi 1. Yogyakarta: BPFE Yogyakarta.

Lestari, Etty Puji. 2005. Penguatan Ekonomi Industri Kecil dan Menengah melalui platfom klaster industri. Jurnal Organisasi dan Manajemen, Volume 6, Nomor 2, September 2010. Universitas Terbuka.

Marijan, Kacung. 2005. Mengembangkan Industri Kecil Menengah Melalui Pendekatan Klaster. INSAN 7 (3):216-225.

Morosini, Piero. 2004. Industrial Clusters, Knowledge Integration, and Performance. World Development 32 (2):305-326.

Nurcomariah, Musa Hubeis, Wini Trilaksani. 2020. Strategy of Developing Seaweed Gracillaria Agribusiness in Karangantu Serang Banten. Jurnal Manajemen Pengembangan IKM. Vol. 15 No. 1 Februari (2020) : $62-69$.

Purnomo, Dwi dan Koko Iwan Agus. 2017. Sociopreneur Milenial; Bisnis Berbasis Kolaborasi antara Desa dan Kota. Bitread Publishing. Bandung. 
Rustandi, Roni. 2017. Kajian Teoritis Fungsi Pemerintah Daerah dan Dewan Perwakilan Rakyat Daerah Dalam Pembentukan Peraturan Daerah Menurut Undang-Undang Nomor 23 Tahun 2014 Tentang Pemerintahan Daerah Sebagaimana Telah Dirubah Dengan UndangUndang Nomor 9 Tahun 2015. Jurnal Surya Kencana Dua: Dinamika Masalah Hukum dan Keadilan Vol. 4 No.1 Juli 2017. Banten.

Setiawan, Teguh Febrianto., Budi Suharjo and Muhammad Syamsun. 2018. Food Online Marketing Strategy for MSME (Case Study in Cibinong District). Jurnal Manajemen Pengembangan IKM. Vol. 13 No. 2 September (2018) : 116 - 126. 